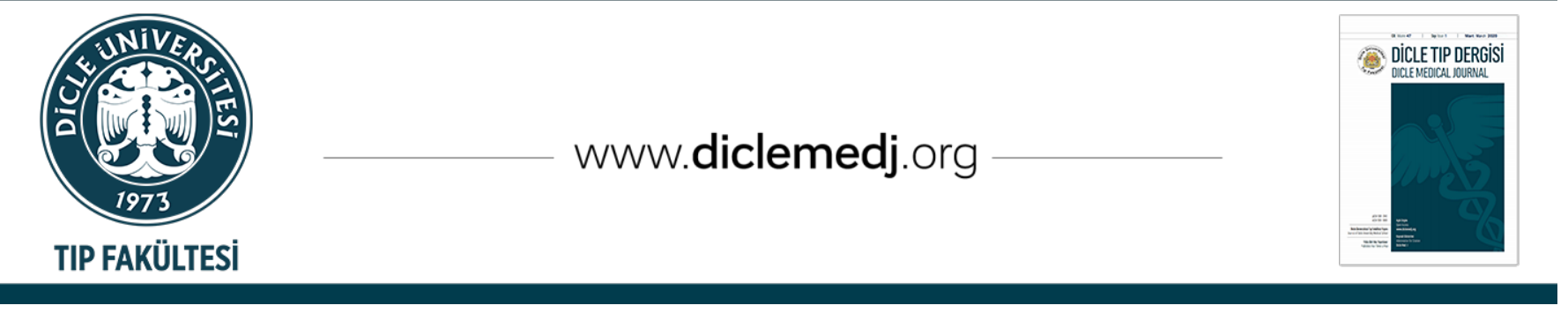

Original Article / Özgün Araştırma

\title{
Evaluation of Corneal Aberration Alterations After Accelerated Transepithelial Corneal Crosslinking
}

\author{
Mehmet Gökhan Aslan ${ }^{1}$, Yavuz Oruç ${ }^{D} 2$ \\ 1 Department of Ophthalmology, Faculty of Medicine, Recep Tayyip Erdogan University, Rize, Turkey \\ 2 Fethi Sekin City Hospital, Ophthalmology Clinic, University of Health Sciences, Elazig, Turkey
}

Received: 14.07.2020; Revised: 13.09.2020; Accepted: 14.09.2020

\begin{abstract}
Objective: This study aimed to report the corneal aberration alterations after accelerated transepithelial corneal crosslinking (A-TE CXL) and to investigate the relationship between corrected distance visual acuity (CDVA) and corneal aberrations.

Methods: Fifty-six eyes of 45 progressive keratoconus (KCN) patients who underwent A-TE CXL were retrospectively evaluated. Total ocular aberrations (TOA), high-order aberrations (HOA), low order aberrations (LOA), and spectacle-CDVA values were recorded preoperatively, 6 , and 12 months after the procedure. The alterations of the parameters were compared and correlation analysis was performed between corneal aberrations and CDVA.
\end{abstract}

Results: The mean age of the patients was $22.23 \pm 3.14$ years. The preoperative, postoperative 6 and 12 months median CDVAs were $0.50(0.20-0.90), 0.60(0.20-1.0)$ and $0.60(0.10-0.90)$, respectively. The preoperative root means square (RMS)-TOA, RMSHOA, and RMS-LOA values were $2.4 \pm 0.88 \mu \mathrm{m}, 1.50 \pm 0.59 \mu \mathrm{m}$, and $1.78 \pm 0.88 \mu \mathrm{m}$, respectively. The CDVA values increased significantly at postoperative- 6 month examinations. After the A-TE CXL procedure, the aberrations were detected as $2.58 \pm 0.94 \mu \mathrm{m}, 1.62 \pm 0.57 \mu \mathrm{m}, 1.90 \pm 0.99 \mu \mathrm{m}$ and $2.38 \pm 0.81 \mu \mathrm{m}, 1.46 \pm 0.57 \mu \mathrm{m}, 1.77 \pm 0.85 \mu \mathrm{m}$ at 6 th and 12 th months, respectively. The TOA and HOA values significantly decreased 6 and 12 months after A-TE CXL. The LOA alterations were not statistically significant. The correlation analysis between corneal aberrations and CDVA revealed no significance at any time point.

Conclusion: Although the TOA and HOA values significantly decreased and CDVA significantly increased in the early postoperative period, a relationship between the CDVA and corneal aberration alterations was not detected. Even the corneal aberration improvement had contributed to the increase in CDVA, evaluation of epithelial structural alterations can be suggested to better understand the clinical outcomes.

Keywords: Corneal aberrations, corneal crosslinking, keratoconus

DOI: 10.5798/dicletip.799987

Correspondence / Yazışma Adresi: Yavuz Oruç, Fethi Sekin City Hospital, Ophthalmology Clinic, University of Health Sciences, Elazig, Turkeye-mail: yvzddr@mynet.com 


\section{Hızlandırılmış Transepitelyal Korneal Çapraz Bağlama Tedavisi Sonrası Korneal Aberasyon Değişimlerinin Değerlendirilmesi}

Öz

Amaç: $\mathrm{Bu}$ çalışma hızlandırılmış transepitelyal korneal çapraz bağlama (H-TE KÇB) tedavisi sonrası korneal aberasyon değișimlerini sunmayı ve korneal aberasyonlar ile düzeltilmiş uzak görme keskinliği (DUGK) arasındaki ilişkiyi incelemeyi amaçladı.

Yöntemler: H-TE KÇB tedavisi uygulanmış 45 progresif keratokonus (KKN) hastasının 56 gözü retrospektif olarak değerlendirildi. Total oküler aberasyonlar (TOA), yüksek sıralı aberasyonlar (YSA), düşük sıralı aberasyonlar (DSA) ve gözlükle DUGK değerleri işlem öncesinde ve 6-12 ay sonrasında kaydedildi. Bu parametrelerin değișimleri karşılaștırıldı ve DUGK ile korneal aberasyonlar arasında korelasyon analizi yapıldı.

Bulgular: Hastaların ortalama yaşı 22.23 \pm 3.14 yıldı. Ameliyat öncesi, 6 ve 12 ay sonrası median DUGK değerleri sırasıyla 0.50 (0.20-0.90), $0.60(0.20-1.0)$ and 0.60 (0.10-0.90) idi. Postoperatif 6.ay muayenesinde DUGK anlamlı olarak artmıştı. Ancak Ameliyat öncesi karekök (KK)-TOA, KK-YSA ve KK-DSA değerleri sırasıyla $2.4 \pm 0.88 \mu \mathrm{m}, 1.50 \pm 0.59 \mu \mathrm{m}$ and $1.78 \pm 0.88 \mu \mathrm{m}$ idi. Ameliyattan 6 ve 12 ay sonra ise bu değerler sırasıyla $2.58 \pm 0.94 \mu \mathrm{m}, 1.62 \pm 0.57 \mu \mathrm{m}, 1.90 \pm 0.99 \mu \mathrm{m}$ ve $2.38 \pm 0.81 \mu \mathrm{m}, 1.46 \pm 0.57 \mu \mathrm{m}$, $1.77 \pm 0.85 \mu \mathrm{m}$ olarak saptandı. TOA ve YSA, H-TE KÇB tedavisi sonrası 6 ve 12. Ayda anlamlı olarak azaldı. DSA değişimleri ise anlamlı değildi.Hiçbir ölçüm zamanında korneal aberasyon değişimleri ile DUGK arasında anlamlı korelasyon saptanmadı.

Sonuç: H-TE KÇB tedavisi sonrası TOA ve HOA değerlerinde anlamlı düşüş, DUGK'de erken postoperatif dönemde anlamlı bir artış olmasına rağmen bu değerler arasında bir ilişki saptanmadı. Tedavi sonrası DUGK artışına korneal aberasyonlardaki iyileşmenin katkısı olsa da, klinik sonuçları daha iyi anlamak için epitel yapısında meydana gelen değişimlerinde değerlendirilmesi önerilebilir.

Anahtar kelimeler: Korneal aberasyonlar, korneal çapraz bağlama, keratoconus.

\section{INTRODUCTION}

Keratoconus (KCN) is progressive thinning of the cornea leading to irregular myopic astigmatism and decreased vision ${ }^{1}$. Its prevalence in the general population varies between $50-230 / 100 \cdot 000^{2}$. A satisfactory visual acuity may not be achieved in most of the patients by conventional methods such as glasses and soft contact lenses due to the increased high-order aberrations (HOAs) ${ }^{3}$.

The only treatment modality to stop keratoconus progression is corneal crosslinking (CXL) ${ }^{4}$. The UV-A irradiated Riboflavin molecules increase the biomechanical strength of the covalent bonds between corneal stromal collagen fibres ${ }^{5}$. Thus, the progression of the disease can be halted and in addition, some secondary benefits can be obtained in terms of the optical properties of the cornea. Currently, accelerated (A) and transepithelial protocols (TE) are available to perform the procedure with increased patient comfort, less risk of infection, and corneal haze 6 .

The corneal aberrations can be measured by three distinct methods; HartmannSchackaberrometer, Scheimpflug based corneal topography, and anterior segment OCT2. The Scheimpflug corneal topography device is widely used in ophthalmology clinics and its repeatability was reported as good to excellent ${ }^{7}$. Particularly the HOA values were determined to increase approximately 5.5 times more in KCN patients compared to the healthy population ${ }^{8}$. It was previously reported that the maximum and mean keratometry (Kmax-Kmean), total ocular aberration (TOA), and HOA measurements were significantly improved after CXL with various treatment protocols9,10. Besides, corneal aberration alterations were suggested as useful indices to monitor CXL treatment success $^{11}$. On the other hand, there were contradictory results whether these changes are correlated with clinical findings ${ }^{12}$. 
Currently, there is no consensus on A-CXL protocols. The UV-A irradiation is performed for 30 minutes with $3 \mathrm{~mW} / \mathrm{cm} 2$ energy in the standard Dresden protocol, whereas, the accelerated protocol can be applied in pulsed or continuous modes with $10-45 \mathrm{~mW} / \mathrm{cm} 2$ energy and irradiation times ranging between 2.4-10 minutes ${ }^{13-15}$. Moreover, the stromal penetration of Riboflavin can be achieved by the mechanical removal of the epithelium (epi-off) or over an intact epithelium (transepithelial) by changing the chemical content of the solution. The modality variations may lead to differences in postoperative topographic results. In this study, we evaluated the corneal aberration alterations in our patients who underwent A-TE CXL. Therefore, we aimed to investigate the relationship between corneal aberration and visual acuity alterations.

\section{METHODS}

This retrospective study included progressive KCN patients who applied to the ophthalmology clinic of a tertiary university hospital and underwent A-TE CXL between January 2018January 2019. Both verbally and written informed consents were acquired from all participants before the procedure. RecepTayyip Erdogan University ethical board committee approval was obtained prior to the study and the researchers committed to follow the tenets of the Declaration of Helsinki.

All patients recruited in the study were ophthalmologically examined including spectacle-corrected visual acuity (CDVA) with Snellen's chart, anterior segment biomicroscopy, fundoscopy, and Sirius corneal topography preoperatively, 6 and 12 months after the A-TE CXL procedure. KCN diagnosis was confirmed by Scheimpflug corneal topography software which was based on keratometer and pachymetry measures. The progression criteria were $\geq 1 \mathrm{D}$ increase of the Kmax, $\geq 20 \mu$ m decrease of the minimal central corneal thickness (MCCT), and $\geq 10 \mu \mathrm{m}$ increase of keratometry vertex front and/or back indices. Patients with at least two of the topographic progression parameters in the last 6 months were recruited in the study. The exclusion criteria for the procedure were; MCCT $<400 \mu \mathrm{m}$, history of autoimmune and collagen tissue disease, neurodermatitis, hydrops sequelae, recurrent corneal erosion, corneal dystrophy, tear dysfunction, herpetic eye disease, deep corneal scar, untreated eyelid disorders, pregnancy, and breastfeeding. Patients with missing data were also excluded. Demographic data, spectacle-CDVA values, TOA, total HOA, and LOA values from central $6 \mathrm{~mm}$ cornea were recorded for analysis.

Accelerated Transepithelial Crosslinking Procedure

The proparacaine hydrochloride $0.5 \%$ (Alcaine, Alcon Labs, USA) drops were instilled for local anesthesia before the procedure. The eye was sterile draped and then the eyelid speculum was inserted. Riboflavin solution was applied to the corneal surface in two steps for ten minutes, one minute apart, without removing the epithelium. In the first step, $0.25 \%$ riboflavin (Paracel Part I, AvedroInc, USA) containing BAC and HPMC was instilled for four minutes. Thereafter $0.22 \%$ riboflavin (ParacelPart II, AvedroInc, USA) was instilled over the next six minutes. The cornea was washed with a isotonic solution to remove excessive riboflavin. The UV-A was applied by the Avedro KXL System (Avedro Inc., Waltham, USA) with $45 \mathrm{~mW} / \mathrm{cm}^{2}$ UV power for 2 minutes and 40 seconds. The total energy of irradiation was $7.20 \mathrm{~J} / \mathrm{cm}^{2}$. Patients were prescribed $0.15 \%$ Na-Hyaluronate (Eyestil, SIFI, Italy) topical artificial tear drops and \%0.5 Moxifloxacin hydrochloride (Vigamox, Alcon Labs, Fort Worth, TX) four times a day for two weeks postoperatively.

\section{Data Analysis}

Statistical analyses were performed using SPSS version 23.0 for Windows (SPSS, Inc., Chicago, 
IL). The normality distribution of the variables were investigated with analytical methods. Repeated measures ANOVA test was used to compare normally distributed values and Friedman test was used to compare nonparametric measures at three-time points. Bonferroni correction was performed for multiple comparisons. The alterations between two-time points were compared by using the Paired samples t-test. The Pearson and Spearmen correlation coefficients were calculated to evaluate the relation between CDVA and corneal aberration alterations. All analyses were performed with a power of $95 \%$ CI. The $\mathrm{p}$ values less than 0.05 were accepted as significant. The post-hoc power analysis was performed by using G*Power v3.1.9.2 program.

\section{RESULTS}

This study included 56 eyes of $45 \mathrm{KCN}$ patients. The calculated power (1-beta) based on this test was 0.993 , considering type I error (alfa) of 0.05 , sample size of 56 , effect size of 0.56 and one-sided alternative hypothesis (H1). The mean age of the patients was $22.23 \pm 3.14$ (1730 ) years. The procedure was applied to 15 right eyes, 19 left eyes, and 11 bilateral cases. The demographic data of the patients are shown in Table-I.

Table I: Demographic data of the patients

\begin{tabular}{|lcccc|}
\hline & Mean & SD & Minimum & Maximum \\
\hline Age & & & & \\
(years) & 22.23 & 3.14 & 17 & 30 \\
& $\mathbf{N}$ & Right & Left & Bilateral \\
Male & 24 & 12 & 5 & 7 \\
Female & 21 & 7 & 10 & 4 \\
Total & 45 & 19 & 15 & 11 \\
\hline
\end{tabular}

The median of CDVA before CXL was 0.50 (0.20$0.90)$. They were $0.60(0.20-1.0)$ and $0.60(0.10-$
0.90 ), respectively at postoperative 6 and 12 months (Figure-I) The postoperative CDVA alteration was statistically significant ( $p$ $=0.002$ ).

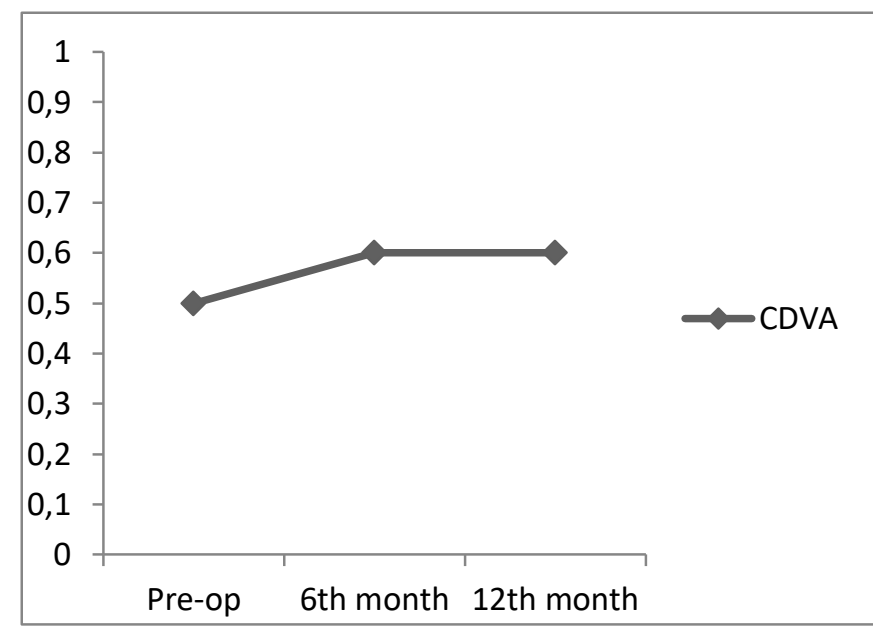

Figure I. The median corrected distance visual acuity (CDVA) alterations after the procedure

The preoperative root means square (RMS)TOA, RMS-HOA, and RMS-LOA values were $2.4 \pm 0.88 \mu \mathrm{m}, 1.50 \pm 0.59 \mu \mathrm{m}$, and $1.78 \pm 0.88 \mu \mathrm{m}$, respectively. After the A-TE CXL procedure, the aberrations were detected as $2.58 \pm 0.94 \mu \mathrm{m}$, $1.62 \pm 0.57 \mu \mathrm{m}, 1.90 \pm 0.99 \mu \mathrm{m}$, and $2.38 \pm 0.81 \mu \mathrm{m}$, $1.46 \pm 0.57 \mu \mathrm{m}, 1.77 \pm 0.85 \mu \mathrm{m}$ at 6 th and 12 th months, respectively. The TOA and HOA were significantly altered however there was no significant change in LOA measurements (Table II-III).

Table II. The CDVA and corneal aberration measurements of the patients

\begin{tabular}{|lccccc|}
\hline & & Pre-op & $\mathbf{6}$ months & 12 months & p \\
\hline CDVA & $\begin{array}{c}0.50(0.20- \\
0.90)\end{array}$ & $\begin{array}{c}0.60(0.20- \\
1.0)\end{array}$ & $\begin{array}{c}0.60(0.10- \\
0.90)\end{array}$ & $\mathbf{0 . 0 0 2}^{\mathbf{a}}$ \\
$\begin{array}{l}\text { RMS } \\
(\boldsymbol{\mu m})\end{array}$ & TOA & $2.58 \pm 0.94$ & $2.40 \pm 0.88$ & $2.38 \pm 0.81$ & $\mathbf{0 . 0 0 1}^{\mathbf{b}}$ \\
$\begin{array}{l}\text { RMS } \\
(\boldsymbol{\mu m})\end{array}$ & HOA & $1.62 \pm 0.57$ & $1.50 \pm 0.59$ & $1.46 \pm 0.57$ & $\mathbf{< 0 . 0 0 1}^{\mathbf{b}}$ \\
$\begin{array}{l}\text { RMS } \\
(\boldsymbol{\mu m})\end{array}$ & LOA & $1.78 \pm 0.88$ & $1.90 \pm 0.99$ & $1.77 \pm 0.85$ & $0.097^{\mathrm{b}}$ \\
\hline
\end{tabular}

CDVA: Corrected distance visual acuity, RMS: root mean square TOA: Total ocular aberrations, HOA: High order aberrations LOA: Low order aberrations, $p<0.05$ significant values are shown in bold a aFriedman's Test bRepeated measures ANOVA 
Table III: The CDVA and corneal aberration alterations of the patients

\begin{tabular}{|c|c|c|c|c|c|c|}
\hline & $\begin{array}{c}\Delta 6 \mathrm{~m}- \\
\text { Pre-op }\end{array}$ & $\mathbf{p}$ & $\begin{array}{l}\Delta 12 \mathrm{~m}- \\
\text { Pre-op }\end{array}$ & $\mathbf{p}$ & $\begin{array}{c}\Delta 12 \mathrm{~m}- \\
6 \mathrm{~m}\end{array}$ & p \\
\hline CDVA & $\begin{array}{c}0.04 \pm 0 \\
06\end{array}$ & $\begin{array}{c}<0.00 \\
1\end{array}$ & $0.02 \pm 0.09$ & 0.090 & $\begin{array}{c}- \\
0.02 \pm 0.0 \\
9\end{array}$ & $\begin{array}{c}0.08 \\
3\end{array}$ \\
\hline $\begin{array}{l}\text { RMS } \\
\text { TOA } \\
(\mu \mathrm{m})\end{array}$ & $\begin{array}{c}- \\
0.17 \pm 0 \\
30\end{array}$ & $\begin{array}{c}<0.00 \\
1\end{array}$ & $\begin{array}{c}- \\
0.20 \pm 0.47\end{array}$ & 0.002 & $\begin{array}{c}- \\
0.02 \pm 0.4 \\
1\end{array}$ & $\begin{array}{c}0.66 \\
9\end{array}$ \\
\hline $\begin{array}{l}\text { RMS } \\
\text { HOA } \\
(\mu \mathrm{m})\end{array}$ & $\begin{array}{c}- \\
0.11 \pm 0 \\
17\end{array}$ & $\begin{array}{c}<0.00 \\
1\end{array}$ & $\begin{array}{c}- \\
0.15 \pm 0.18\end{array}$ & $\begin{array}{c}<0.00 \\
1\end{array}$ & $\begin{array}{c}- \\
0.04 \pm 0.2 \\
1\end{array}$ & $\begin{array}{c}0.16 \\
8\end{array}$ \\
\hline $\begin{array}{l}\text { RMS } \\
\text { LOA } \\
(\mu \mathrm{m})\end{array}$ & $\begin{array}{c}0.12 \pm 0 \\
33\end{array}$ & 0.094 & $\begin{array}{c}- \\
0.008 \pm 0.4 \\
9-\end{array}$ & 0.909 & $\begin{array}{c}- \\
0.12 \pm 0.5 \\
7\end{array}$ & $\begin{array}{c}0.14 \\
4\end{array}$ \\
\hline
\end{tabular}

CDVA: Corrected distance visual acuity, RMS: Root mean square TOA: Total ocular aberrations, HOA: High order aberrations, LOA: Low order aberrations, $p<0.05$ significant values are shown in bold Paired Samples ttest

The analysis of CDVA alterations over time revealed a significant increase at 6 months $(\mathrm{p}<0.001)$ however, the CDVA alterations were not significant between preoperative-12 months and 6-12 months $(\mathrm{p}=0.090, \mathrm{p}=0.083$, respectively), (Table-III). The Pearson and Spearmen correlation analyses between corneal aberrometry alterations and CDVA revealed no significant correlation at any time interval ( $p>0.05$, for all).

\section{DISCUSSION}

In this study, we detected lower corneal TOA and HOA values at 6 and 12 months after A-TE CXL compared to preoperative values. Nevertheless, the LOA alterations were not statistically significant. The CDVA values increased significantly at postoperative- 6 month examinations. However, we did not find any significant correlation between CDVA and corneal aberration alterations at any time interval.

The monochromatic aberrations of the eye are described in two groups; HOAs and LOAs ${ }^{16}$. The LOAs are associated with spherical and cylindrical refractive disorders and can be reduced by glasses and soft contact lenses.
However, the failure of these refractive corrections in KCN patients was explained by the increased HOAs ${ }^{17}$. The normal value of total HOAs in the healthy population is around $0.30 \mu \mathrm{m}$, however, several studies detected higher HOAs in KCN patients ranging between $0.71-10.94 \mu \mathrm{m}^{12,18,19}$. The mean of preoperative HOAs was $1.62 \pm 0.57 \mu \mathrm{m}$ in our study. Similarly, due to myopic astigmatism caused by KCN, the mean LOA value was also higher compared to healthy individuals. Since the CXL procedure aims to stop the progression of KCN rather than treating the disease, it is reasonable that no significant alterations occurred in terms of LOA values.

Previous studies suggested that corneal aberrations may alter due to the changes in the corneal architecture after CXL treatment. Momena et al reported that the HOA values decreased significantly 6 months after A-TE CXL (pulsed $45 \mathrm{~mW} / \mathrm{cm} 2,5$ minutes 20 seconds) ${ }^{20}$. Consistently, we also detected significant reductions in both TOA and HOA values compared to baseline 6 and 12 months after ATE CXL. Nonetheless, Caporossi et al reported no significant change in terms of HOA after epioff $\mathrm{CXL}^{21}$. It was previously explained that a better epithelial remodeling on the corneal surface may occur after epi-on CXL applications ${ }^{22}$. Therefore, a smoother ocular surface may contribute to the reduction of corneal aberrations.

There are contradictory results regarding CDVA alterations after CXL treatment.Bozkurt et al reported increased CDVA after A-TE CXL, on the other hand, few reports detected no significant changes $^{23-25}$. In this study, there was a significant increase in CDVA 6 months after the procedure. However, although an increase was observed after 12 months compared to the initial examination, this difference was not statistically significant. In the epi-on CXL method, the epithelium is protected from mechanical trauma, which also prevents 
complications such as corneal haze and infiltrates in the postoperative period. Thus, a cleaner optical surface may contribute to the significant increase of CDVA after the CXL procedure. Nevertheless, this effect would be limited and CDVA improvement may stabilize in the long term. Greenstein et al reported no correlation between corneal HOA improvement and visual acuity ${ }^{26}$. We also detected no correlation between CDVA and corneal aberrations. It can be explained by two hypotheses; firstly, KCN is an asymmetric progressive disease, and CDVA alterations may occur randomly. Even though HOAs were reduced after CXL, the spectacles and soft contact lenses may underperform due to high astigmatism. The hybrid or scleral contact lenses can achieve a more significant reduction in HOAs, resulting in better CDVA values. However, none of the patients included in this study were using these lenses. Hence, we could purely observe the effect of CXL on HOA alterations. Secondly; CDVA examination is a subjective method, which may influence the results according to the manner of the patient and observer. Besides, HOAs cause poor quality of vision due to halo and glare effects ${ }^{27}$. Therefore, utilizing objective methods that can evaluate both visual acuity and quality can be suggested to better understand the relationship between corneal aberrations and visual performance.

This study had some limitations. We excluded the patients with missing data due to the retrospective design of the study. Therefore, the sample size was small. Besides, comparing the transepithelial procedure with epi-off protocol applied controls would provide valuable data to assess the role of corneal epithelium on aberrations after the CXL procedure.

As a conclusion, we detected that TOA and HOA values significantly decreased 6 and 12 months after A-TE CXL procedure and CDVA was significantly increased in the 6th-month examinations. However, the aberration alterations were not significantly correlated with CDVA. Further studies that objectively determine corneal epithelial anatomic alterations with different treatment protocols and larger patient groups may help to better understand the effect of corneal aberration alterations on visual outcomes after the CXL procedure.

Ethics Board Approval: RecepTayyip Erdoğan University Ethics Board Approval was obtained on 09/07/2020 (No: 40465587-050.01.04179)

Declaration of Conflicting Interests: The authors declare that they have no conflict of interest relevant to this study.

Financial Disclosure: No financial support was received.

\section{REFERENCES}

1. Lin DTC, Holland S, Tan JCH, et al. Clinical results of topography-based customized ablations in highly aberrated eyes and keratoconus/ectasia with crosslinking. J Refract Surg. 2012; 28: 841-8.

2. Suzuki N, Yamaguchi T, Tomida D, et al. Impact of corneal higher-order aberrations on visual acuity after deep anterior lamellar keratoplasty in treating keratoconus. Eye Contact Lens. 2019;45: 238-45.

3. Oliveira CM, Ferreira A, Franco S. Wavefront analysis and Zernike polynomial decomposition for evaluation of corneal optical quality. J Cataract Refract Surg. 2012; 38: 343-56.

4. Ağca A, Tülü B, Yaşa D, et al. Accelerated corneal crosslinking in children with keratoconus: 5-year results and comparison of 2 protocols. J Cataract Refract Surg. 2020; 46: 517-23.

5. Wollensak G, Spoerl E, Seiler T. Riboflavin/ultraviolet-A-induced collagen crosslinking for the treatment of keratoconus. Am J Ophthalmol. 2003; 135: 620-7.

6. Hammer A, Richoz O, Mosquera SA, et al. Corneal biomechanical properties at different corneal crosslinking (CXL) irradiances. Investig Ophthalmol Vis Sci. 2014; 55: 2881-4. 
7. Kumar M, Shetty R, Jayadev C, et al. Repeatability and agreement of five imaging systems for measuring anterior segment parameters in healthy eyes. Indian J Ophthalmol. 2017; 65: 288-94.

8. Pantanelli S, MacRae S, Jeong TM, et al. Characterizing the wave aberration in eyes with keratoconus or penetrating keratoplasty using a high-dynamic range wavefront sensor. Ophthalmology. 2007; 114:2013-21.

9. Greenstein SA, Fry KL, Hersh MJ, et al. Higherorder aberrations after corneal collagen crosslinking for keratoconus and corneal ectasia. J Cataract Refract Surg. 2012; 38: 292-302.

10. Kocamiş SI, Çakmak HB, Uğurlu N, et al. Keratokonusta çapraz bağlama tedavisinin konus kırıcılığı ve yüksek sıralı corneal aberasyonlar üzerine etkisi. Turk Oftalmoloiji Derg. 2014; 44: 184-9.

11. Ghanem RC, Santhiago MR, Berti $\mathrm{T}$, et al. Topographic, corneal wavefront, and refractive outcomes 2 years after collagen crosslinking for progressive keratoconus. Cornea. 2014; 33: 43-8.

12. Nattis AS, Rosenberg ED, Donnenfeld ED. Oneyear visual and astigmatic outcomes of keratoconus patients following sequential crosslinking and topography-guided surface ablation: the TOPOLINK study. J Cataract Refract Surg. 2020; 46: 507-16.

13. Wollensak G. Crosslinking treatment of progressive keratoconus: New hope. Curr Opin Ophthalmol. 2006; 17: 356-60.

14. Kirgiz A, Eliacik M, Yildirim Y. Different accelerated corneal collagen cross-linking treatment modalities in progressive keratoconus. Eye Vis. 2019; 6: 1-9.

15. Omar IAN, Zein HA. Accelerated epithelium-off corneal collagen cross-linking for keratoconus: 12month results. Clin Ophthalmol. 2019;13: 2385-94.

16. Vinciguerra $\mathrm{P}$, Albè E, Trazza $S$, et al. Refractive, topographic, tomographic, and aberrometric analysis of keratoconic eyes undergoing corneal cross-linking. Ophthalmology. 2009; 116: 369-78.

17. Özülken K, Aydemir GA, Aydemir E, Kızıltoprak $H$, Yüksel E. Comparison of two different accelerated corneal cross-linking procedure outcomes in patients with keratoconus. Balkan Med J. 2020;37:131-7.

18. Hashemi H, Khabazkhoob M, Jafarzadehpur E, et al. Higher order aberrations in a normal adult population. J Curr Ophthalmol. 2015; 27: 115-24.

19. Iselin KC, Baenninger PB, Bachmann LM, et al. Changes in higher order aberrations after central corneal regularization - a comparative two-year analysis of a semi-automated topography-guided photorefractive keratectomy combined with corneal cross-linking. Eye Vis. 2020; 7: 1-10.

20. Momena AA.,Moamen S., Ahmed A., Tamer EM., Rafeek EG. Assessment of corneal higher order aberrations before and after corneal collagen crosslinking in patients with keratoconus. Egypt J Hosp Med. 2018; 72: 4100-3.

21. Caporossi A, Mazzotta C, Paradiso AL, et al. Transepithelial corneal collagen crosslinking for progressive keratoconus: 24-month clinical results. J Cataract Refract Surg. 2013; 39: 1157-63.

22. Haberman ID, Lang PZ, Broncano AF, et al. Epithelial remodeling after corneal crosslinking using higher fluence and accelerated treatment time. J Cataract Refract Surg. 2018; 44: 306-12.

23. Bozkurt E, Ozgurhan EB, Akcay BIS, et al. Refractive, topographic, and aberrometric results at 2-Year follow-up for accelerated corneal cross-link for progressive keratoconus. J Ophthalmol. 2017; 2017: 5714372.

24. Ozgurhan EB, Akcay BIS, Kurt T, et al. Accelerated corneal collagen cross-linking in thin keratoconic corneas. J Refract Surg. 2015; 31: 386-90.

25. Kaydu E, Erbağcı İ, Okumuş S, Aksoy Ü. The results of cross-linking with riboflavin/UV-A in patients with progressive keratoconus. Dicle Med J / Dicle Tip Derg. 2016; 43: 67-72.

26. Greenstein SA, Chung D, Rosato L, Gelles JD, Hersh PS. Corneal higher-order aberrations after crosslinking and intracorneal ring segments for keratoconus. J Cataract Refract Surg. 2020; 46: 97985.

27. Applegate RA, Hilmantel G, Howland HC, et al. Corneal first surface optical aberrations and visual performance. J Refract Surg. 2000; 16: 507-14. 